\title{
Projects Management for SMEs Recovery in Riohacha, Colombia
}

\author{
Jaider Curiel De Luque ${ }^{1}$, Danny Daniel López Juvinao ${ }^{2 *}$ and Alma Luisa Fonseca Mendoza ${ }^{3}$ \\ 'Riohacha, Colombia; jaider23@gmail.com \\ ${ }^{2}$ Research Group, IPAITUG, Universidad de La Guajira, Colombia; \\ dlopezj@uniguajira.edu.co \\ ${ }^{3}$ Research Group, COMPLEXUS, Universidad de La Guajira, Colombia
}

\begin{abstract}
Objectives: The purpose of this article is to analyze the projects management for SMEs recovery in Riohacha, Colombia. Materials and Methods: This research is descriptive, with a non-experimental field design. It is a transverse study. Findings: Sometimes SMEs managers or assistance managers apply an appropriate management model for its company's recovery projects in the industrial sector of Riohacha. Application/Improvements: To optimize the current situation of projects management, improving characteristics and requirements of the industrial sector's SMEs in Riohacha.
\end{abstract}

Keywords: Project Management, Recovery, Design, SMEs

\section{Introduction}

The policies to support SMEs in Colombia has been defined by changes in the countries' financial and development policies which are influenced by different ruling development models. These policies go from the substitution of importations until the so-called opening policies which are reflected in structural reforms launched in the early nineties.

The study developed by the Colombian Chamber of Commerce in 2010 showed that SMEs main problems are: vulnerability to the market changes, lack of training and knowledge of administrative and financial subjects, lack of liquid funds, problems with the partners, outdated technology, portfolio balance.

According to the National Statistics Administrative Department (DANE 2008) there are approximately 1.180.000 micro enterprises and 36.674 small enterprises, distributed in the following areas: commerce, services, and industry. The Colombian Societies Superintendence reports that medium sized businesses are involve in the following activities: trade and repairing of vehicles (31\%), manufacturing industry (20\%), real estate businesses and rental activities (16\%) construction (10\%). The small businesses are involved mostly with: trade (34\%), real estate businesses and rental activities (20\%), manufacturing industry (16\%) construction (9\%).

The numbers of SMEs participation in the Colombian Gross Domestic Product (PIB) is seen in the quantity of employment generated by these businesses. According to the survey developed by DANE in 2012, the staff is distributed as follows: $50,3 \%$ for the micro enterprises, $17,6 \%$ for small enterprises, $12,9 \%$ for medium sized enterprises and $19,2 \%$ for big enterprises. The above means that SMEs employs 30,5\% of the staff in Colombian companies. And

${ }^{*}$ Author for correspondence 
the micro or small sized enterprises are the main source of employment generation in Colombia with an $81 \%$.

The importance of SMEs for Colombia is reflected in its monthly sales (in Riohacha specifically). According to DANE during the last twelve months (October 2011 to September 2012) the businesses' monthly average of production, sales or income was of 7,4 million pesos for the 36.954 economic units, and the monthly average of production, sales or income per person was of 3.4 million pesos.

In Colombia, cities like Riohacha has SMSs as the main source of income. According to the Guajira Chamber of Commerce there are 56700 small sized enterprises and 12 medium sized enterprises. The economy in this department depends on SMEs, that is why it's recovery will bring about changes in the competitive environment and in the ability to develop strategic projects, both strategically and corporative. This way it will overcome the different problems existing in the market.

In the same way, the current Colombian government has designed different policies to help SMEs development in Riohacha, motivating the productive transformation and the improvement of competitivity; as well as adding small sized businesses and looking its formalization. Among the benefits to improve the SMEs situation in Colombia, there is its progress in the competitivity area. It is important not only for its incursion in new markets but also to strengthen it in an inside level. The government supports this idea offering credits and free business courses.

Projects management is the application of knowledge, abilities, tools and technics of the project activities in order to accomplish its requirements. Projects management is carried out through the use of processes such as: induction, planning, execution, control and end. It is important to add that the team of the project manage the work of the projects, which commonly involve demands of time, cost, risk, quality and also clients with different needs and expectations ${ }^{\underline{1}}$.

Also, projects management is a tool for companies, and it is a consequence of its changes, innovation and creativity. It is important to say now that when enterprises decide to invest in innovation, it creates a team dedicated only to this innovation project. The team is responsible for defining the objectives, planning the way to accomplish it, execute the process, and finally finish it successfully with a new innovation, product, service or process 2 .

On the other hand, the company's situation analysis related to the current market strengths, the competitivity, the evolution and current result situations. The objective of this detailed analysis is to discover the determining factors of the business success or failure, which could be unseen in the everyday ${ }^{3}$.

In general terms, the projects are designed as an answer to a development problem or obstacle. Frequently, not always, this problem is originated in a public service which provides a very bad service or does not exist. Many times, there is an agreement where the current situation is unsatisfactory and requires an intervention. Consequently, the current situation is transformed -through a Project- in a desirable future situation. Its study is diagnosed through the identification of the people involve and the analysis of the problems ${ }^{4}$.

In that sense, this research suggest that companies work in convenient conditions with the new business's models. Reverting, motivating and creating positive expectations in the enterprises which invite them to generate inversions to revitalize its productivity. The purpose of this article is to analyze the SMEs recovery projects management in Riohacha, Colombia.

\section{Material and Methods}

This research is descriptive ${ }^{5}$, with a field design ${ }^{6}$, nonexperimental type ${ }^{7}$. It is a transverse study ${ }^{8}$.

The sample was formed by 53 SMEs' managers and / or assistant managers of the industrial sector in Riohacha, Colombia. In order to collect the data, the total of the sample was taken (Table 1), which was considered as a sample census ${ }^{9}$.

The measuring 10 technique selected was the survey. A Likert scale type questionnaire was built with 57 items. When entering the data found in the Statistics Package for Social Sciences (SPSS), we obtained the Cronbach's Alpha 
Table 1. Sample distribution

\begin{tabular}{|c|c|}
\hline Sample & Total \\
\hline SMEs Manager and/or Assistant Managers of the Industrial Sector & 53 \\
\hline
\end{tabular}

Table 2. Measurement scale

\begin{tabular}{|c|c|c|c|}
\hline Choice & Value & Intervals & Category \\
\hline Never & 1 & $1.00-1.80$ & Very low \\
\hline Almost Never & 2 & $1.81-2.60$ & low \\
\hline Sometimes & 3 & $2.61-3.40$ & Moderate \\
\hline Almost Always & 4 & $3.41-4.20$ & High \\
\hline Always & 5 & $4.21-5.00$ & Very High \\
\hline
\end{tabular}

Coefficient which determined the reliability of the instrument, indicating that there was a very high reliability.

The data was tabulated for the descriptive analysis, the distribution of absolute and relative frequencies; also, arithmetic means were found, both per dimensions and indicators, which reflects the data of an organization matrix. Finally, a scale (Table 2) was used to read the results of the arithmetic means.

\section{Results and Discussion}

Dimension: Projects Management Current Situation (Table 3 ) it was observed this variable showed a median of 3.13; in a Moderate Category, ranking below of the median variable; which indicates that the industrial sector's SMEs managers or assistant managers sometimes pay attention to the current situation of their projects management.

In this regard, according to ${ }^{3}$ the analysis of the enterprise situation in relation to the current market forces, the competitive position, the evolution and the current situation of its results. The objective of this detailed analysis of the situation is to discover the determining factors in the success or failure of the business, which could pass as unseen in the business day to day.

Therefore, it is necessary to deepen the analysis of the market and company situation in order to get a better understanding of the client's needs, the competition, and the distribution channel's situation, as well as the positioning of the company, its margins and profitability. The identification of the company success' key factors requires a precise and complete analysis of the situation. The best place to begin the analysis of the situation is the study of the market's demand.

Dimension: SMEs Characteristics (Table 4) it was obtained a median of 3.29 in a Moderate category, ranking above the average of the variable. In this regard 11 considers that small and medium sized enterprises are important because they play a fundamental role in the processes of innovation and technological changes, and also because they have a great capacity to generate employments, where its productive processes are characterized by its integrity in the labor factor. All this helps to 
Table 3. Dimension: Projects management current situation

\begin{tabular}{|c|c|c|c|c|c|c|c|c|c|c|c|c|c|c|c|c|}
\hline \multirow{2}{*}{$\begin{array}{l}\text { Dimen- } \\
\text { sion }\end{array}$} & \multirow{2}{*}{$\begin{array}{l}\text { Indic- } \\
\text { ators }\end{array}$} & \multirow{2}{*}{ Items } & \multicolumn{2}{|c|}{ Always } & \multicolumn{2}{|c|}{$\begin{array}{l}\text { Almost } \\
\text { Always }\end{array}$} & \multicolumn{2}{|c|}{$\begin{array}{l}\text { Some- } \\
\text { times }\end{array}$} & \multicolumn{2}{|c|}{$\begin{array}{l}\text { Almost } \\
\text { Never }\end{array}$} & \multicolumn{2}{|c|}{ Never } & \multicolumn{2}{|c|}{ Total } & \multirow{2}{*}{$\begin{array}{l}\text { Ave- } \\
\text { rage }\end{array}$} & \multirow{2}{*}{$\begin{array}{c}\text { Dime- } \\
\text { nsion } \\
\text { Ave- } \\
\text { rage }\end{array}$} \\
\hline & & & FA & $\%$ & FA & $\%$ & FA & $\%$ & FA & $\%$ & FA & $\%$ & FA & $\%$ & & \\
\hline \multirow{22}{*}{$\begin{array}{c}\text { Projects } \\
\text { manage- } \\
\text { ment } \\
\text { current } \\
\text { situ- } \\
\text { ation }\end{array}$} & \multirow{3}{*}{$\begin{array}{c}\text { Scope } \\
\text { Manage- } \\
\text { ment }\end{array}$} & 1 & \multirow{3}{*}{5} & \multirow{3}{*}{9.4} & \multirow{3}{*}{11} & \multirow{3}{*}{20.8} & \multirow{3}{*}{24} & \multirow{3}{*}{45.3} & \multirow{3}{*}{6} & \multirow{3}{*}{11.3} & \multirow{3}{*}{7} & \multirow{3}{*}{13.2} & \multirow{3}{*}{53} & \multirow{3}{*}{100} & \multirow{3}{*}{3.03} & \multirow{21}{*}{3.13} \\
\hline & & 2 & & & & & & & & & & & & & & \\
\hline & & 3 & & & & & & & & & & & & & & \\
\hline & Objec- & 4 & & & & & & & & & & & & & \multirow{3}{*}{3.06} & \\
\hline & tives & 5 & 4 & 7.5 & 8 & 15.1 & 29 & 54.7 & 11 & 20.8 & 1 & 1.9 & 53 & 100 & & \\
\hline & ment & 6 & & & & & & & & & & & & & & \\
\hline & \multirow{3}{*}{$\begin{array}{c}\text { Time } \\
\text { Manage- } \\
\text { ment }\end{array}$} & 7 & & & & & & & & & & & & & & \\
\hline & & 8 & 8 & 15.1 & 11 & 20.8 & 25 & 47.2 & 7 & 13.2 & 2 & 3.8 & 53 & 100 & 3.25 & \\
\hline & & 9 & & & & & & & & & & & & & & \\
\hline & Reso- & 10 & & & & & & & & & & & & & & \\
\hline & $\begin{array}{c}\text { urces } \\
\text { Manage- }\end{array}$ & 11 & 6 & 11.3 & 11 & 20.8 & 26 & 49.1 & 9 & 17.0 & 1 & 1.9 & 53 & 100 & 3.17 & \\
\hline & ment & 12 & & & & & & & & & & & & & & \\
\hline & Onolitw & 13 & & & & & & & & & & & & & & \\
\hline & Manage- & 14 & 5 & 9.4 & 10 & 18.9 & 32 & 60.4 & 6 & 11.3 & 0 & 0 & 53 & 100 & 3.20 & \\
\hline & & 15 & & & & & & & & & & & & & & \\
\hline & & 16 & & & & & & & & & & & & & & \\
\hline & Manage- & 17 & 4 & 7.5 & 10 & 18.9 & 28 & 52.8 & 8 & 15.1 & 3 & 5.7 & 53 & 100 & 3.05 & \\
\hline & & 18 & & & & & & & & & & & & & & \\
\hline & & 19 & & & & & & & & & & & & & & \\
\hline & Manage- & 20 & 2 & 3.8 & 12 & 22.6 & 33 & 62.3 & 4 & 7.5 & 2 & 3.8 & 53 & 100 & 3.13 & \\
\hline & mert & 21 & & & & & & & & & & & & & & \\
\hline & $\begin{array}{r}\text { Medi } \\
\text { Dimen } \\
\text { Categ }\end{array}$ & $\begin{array}{l}\text { an } \\
\text { ion } \\
\text { ry }\end{array}$ & & Mode & & som & tat & $\begin{array}{l}e \text { ind } \\
\text { arry }\end{array}$ & the & $\begin{array}{l}\text { ctors } \\
\text { rojec }\end{array}$ & mar & $\begin{array}{l}\text { nana } \\
\text { geme }\end{array}$ & $\mathrm{t}$ pr & assista & at $\mathrm{m}$ & \\
\hline
\end{tabular}


Table 4. Dimension: SMEs characteristics

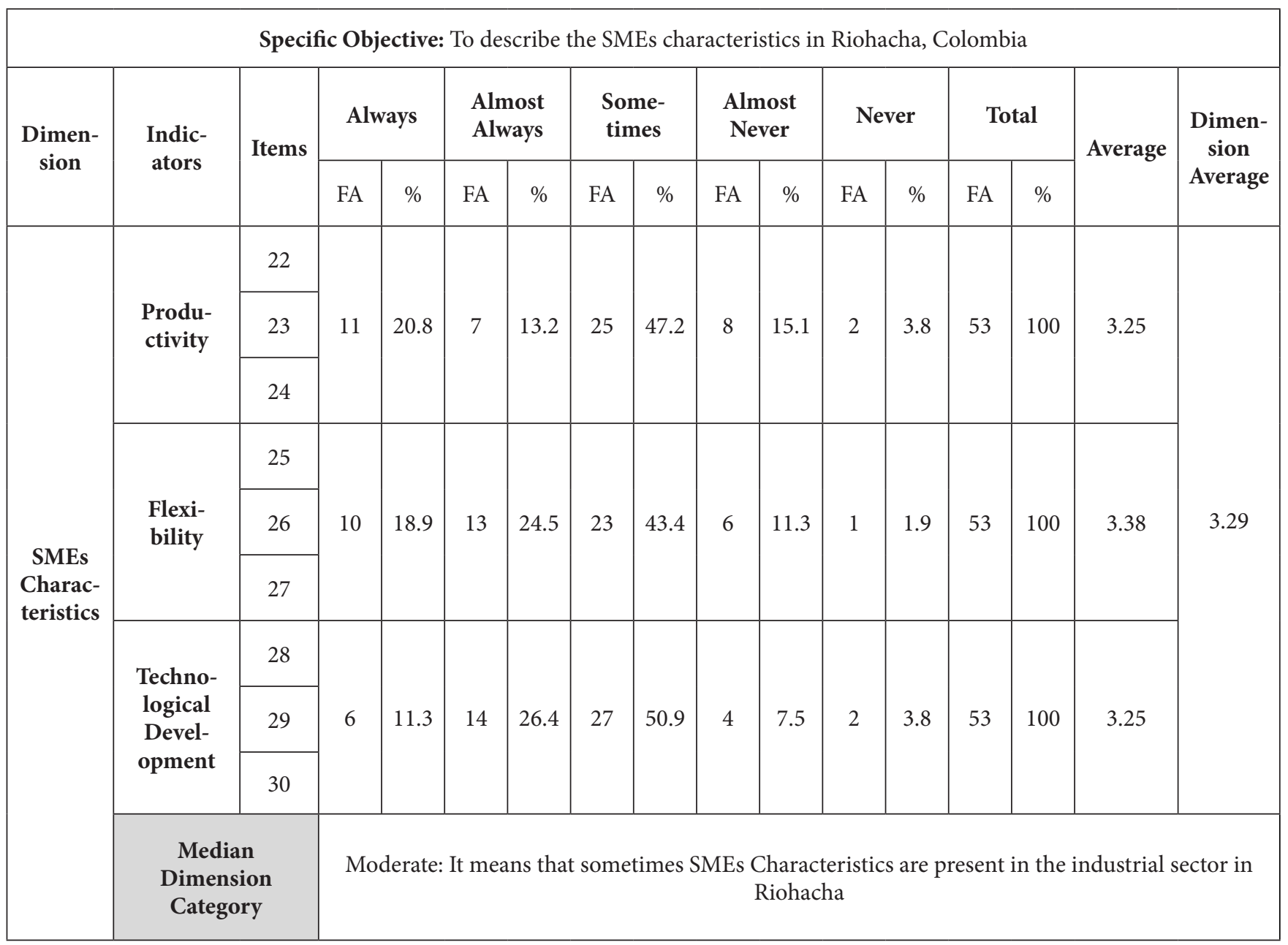

a better distribution of the national income and a greater social development.

With this understanding ${ }^{12}$ points out that small and medium sized enterprises (SMES), whatever its degree of technological development, plays an important role as generators and distributors of the national income. Its ability to employ low-skilled labor during the initial stages of the industrialization processes, makes them a factor of social stability. They also contribute to democratize the capital and to distribute the income because they are less focused on the industrial areas.

In conclusion, according to ${ }^{\frac{13}{3}}$, SMEs reduce the social relations to closer ties in professional terms between employer and employee, favoring labor connections, its origins are family units. It is important to add that this type of enterprises present a greater technological adaptability and lower cost of infrastructure, and it obtains scale economy through the inter-enterprise cooperation, without having to collect the investment in a single firm.

Dimension: Requirement for project's management (Table 5), showed an average of 3.22 placed in a Moderate category above the median variable. Based on these approaches it is relevant to emphasized the importance of applying these requirements to improve the processes because it will allow SMEs to identify the important processes in the value chain. After that structural improvements could be applied which are usually related to the elimination of reprocesses, activities with no value, lost efforts, unnecessary work division, and inconsistency? 
Table 5. Dimension: Model requirement for projects management

Specific Objective: To establish the model requirements for the SMEs recovery project's management in Riohacha, Colombia

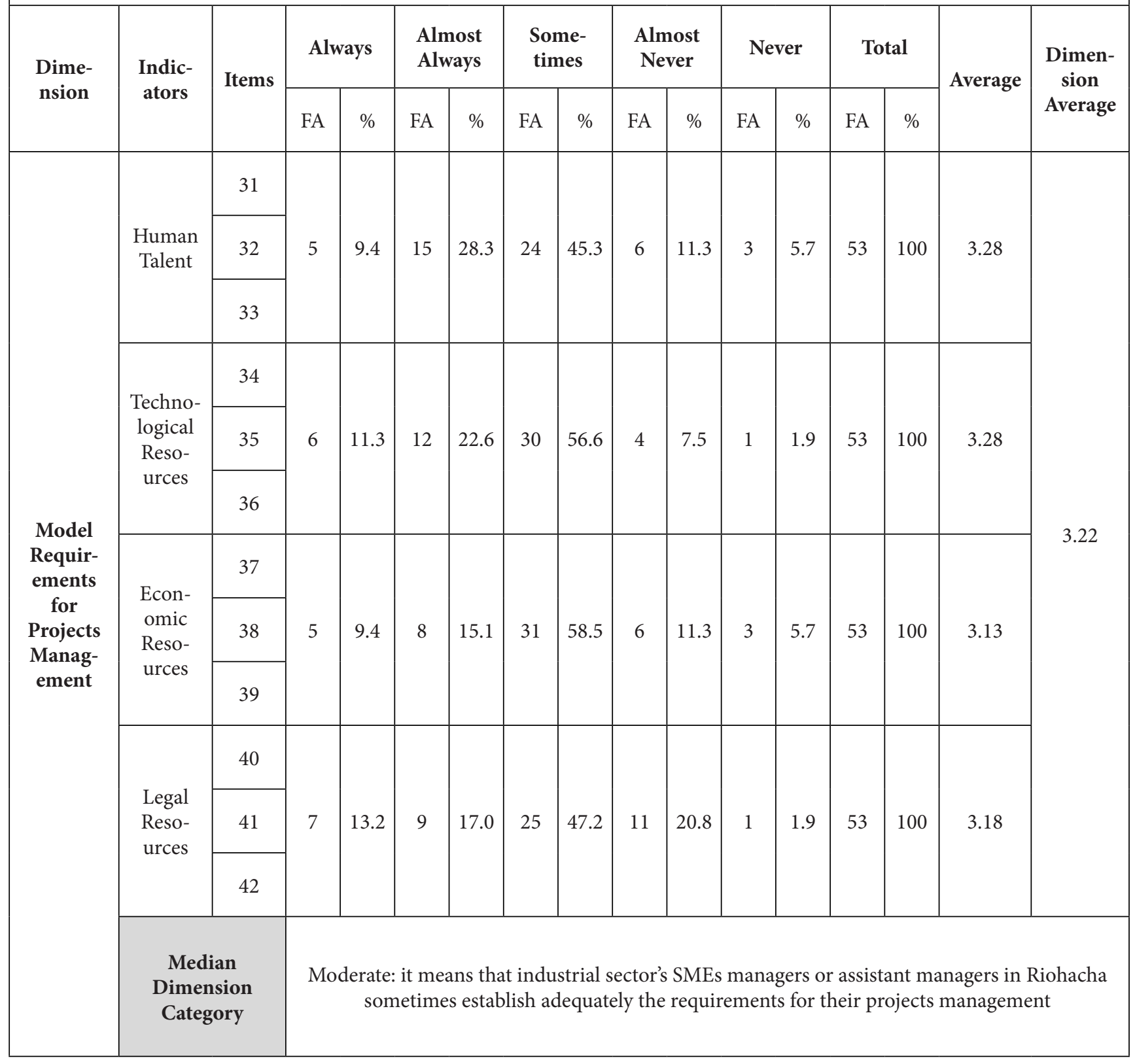

Dimension: Model Phases for Projects Management (Table 6), got a median of 3.11, placing itself in a Moderate category, which locates it under the median of the variable. It means that sometimes meets the model phases for the SMEs projects management recovery in Riohacha.
The above indicates that after a visualization phase better alternative are selected to carry out the project. $\operatorname{In}^{4}$ basically considers the studies to do before making the formal decision of directing or not the resources towards an objective. These phases include the process of identi- 
Table 6. Dimension: Model phases for projects' management

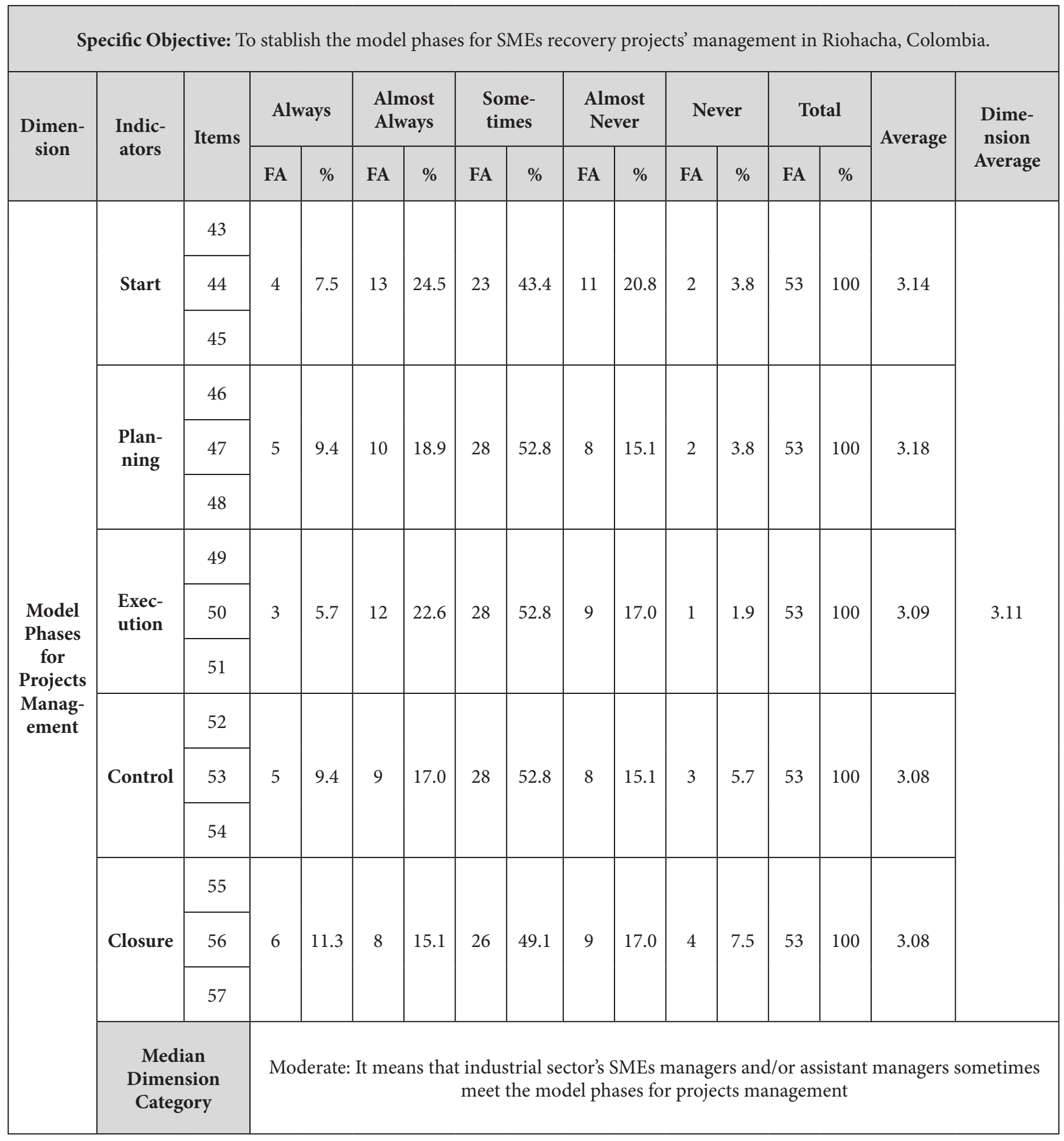

fication, formulation, evaluation and negotiation of the project. This way we can adjust the demands of the project in a better way.
(Table 7) presents the results for the analysis and the debate of this research variable, which was applied to 53 individuals. The median category of the variable Projects 
Table 7. Variable: Projects management

\begin{tabular}{|c|c|c|c|}
\hline Variable & Dimension & Average & Dimension Average \\
\hline \multirow{4}{*}{$\begin{array}{c}\text { Model for SMEs } \\
\text { Projects' Management } \\
\text { Recovery }\end{array}$} & $\begin{array}{c}\text { Projects Management Current } \\
\text { Situation }\end{array}$ & 3.13 & \multirow{4}{*}{3.19} \\
\hline & SMEs Characteristics & 3.29 & \\
\hline & $\begin{array}{l}\text { Projects Management } \\
\text { Requirements }\end{array}$ & 3.22 & \\
\hline & $\begin{array}{c}\text { Model Phases for Projects } \\
\text { Management }\end{array}$ & 3.12 & \\
\hline $\begin{array}{l}\text { Median Dimension } \\
\text { Category }\end{array}$ & \multicolumn{3}{|c|}{ Moderate } \\
\hline
\end{tabular}

Management was Moderate, which means that sometimes managers and/or assistant managers of the SMES in Riohacha apply the appropriate management model for the recovery of their enterprises.

The above indicates that the author ${ }^{14}$ point of view is applied moderately. It means that we need to improve the decision making in relation to the assignment of resources, in order to achieve objectives through the mobilization of adequate means to obtain it. It can be verified in the Projects Management cycle, which supposes a detailed and essential attention to all the steps of a project; from its conception as an idea, until the final or subsequent evaluation, going through all the stages.

\section{Conclusions}

First, it is concluded that sometimes managers or assistant managers of Riohacha's industrial sector SMEs, carry out the project management in an appropriate way. This is especially true for indicators such as: Scope Management, Objectives Management, Cost Management and Risk Management; which were placed below the median of the dimension. Also, it was concluded that sometimes the characteristics of the SMEs are present in the industrial sector of Riohacha; this was evident in the fact that the indicators productivity and technological development were placed below the median of the dimension.

In the same way, managers or assistant managers of Riohacha's industrial sector SMEs sometimes establish the requirements for their projects management appropriately. This is confirmed by the indicators Economic and Legal Resources which placed it below the median of the dimension. Finally, we can conclude that managers or assistant managers of Riohacha's industrial sector SMEs sometimes meet the model phases of the projects managements. This is confirmed by the indicator Execution, Control and Closing which placed it below the median of the dimension.

\section{References}

1. Oca-a J. Gestión de proyectos con mapas mentales. Editorial Club Universitario. Espa-a; 2013. p. 1-295.

2. Martínez L. Gestión del cambio y la innovación en la empresa. Ideas propias Editorial S.L. Espa-a; 2006.

3. Best R. Marketing Estratégico. Pearson editorial. Madrid; 2007.

4. Miranda J. Gestión de proyectos: identificación, formulación, evaluación financiera-económica-social-ambiental. MM Editores. México; 2005. p. 1-381.

5. Chávez N. Introducción a la investigación educativa. 3ra Edición. Editorial la columna. Maracaibo; 2001. p. $1-325$. 
6. Bavaresco A. Proceso metodológico en la investigación. (Cómo hacer un Dise-o de Investigación). 5ta Edición. Editorial de la Universidad del Zulia. Maracaibo, Venezuela; 2006.

7. De Pelekais C, El Kadi O, Seijo C, Neuman N. El ABC de la investigación. Segunda edición. Ediciones Astro Data. Maracaibo, Venezuela; 2010.

8. Hernández R, Fernández C, Baptista M. Metodología de la Investigación. 5a Edición. McGraw Hill Educación. México; 2010.

9. Tamayo M. El Proceso de la Investigación Científica. 4ta Edición. Editorial Limusa. México; 2007.

10. Hurtado I, Toro J. Paradigmas y métodos de investigación en tiempos de cambio. Editorial CEC, S.A. Los Libros de El Nacional. Caracas, Venezuela; 2007.
11. Rebollo L. Diagnóstico de operaciones de las Pymes. 1 Edición. Editorial Trillas. México; 2005. p. 1-167.

12. Urdaneta T. Procedimiento empleados por las peque-as y medianas empresas del municipio sanfrancisco para controlar las finanzas. Universidad Rafael Urdaneta. Maracaibo, Venezuela; 2006. PMCid:PMC1522064

13. Cardozo J. Mecanismos de financiamiento e inversión proporcionados por la banca universal a las Pymes. Universidad Rafael Urdaneta. Maracaibo, Venezuela; 2008.

14. Cano L. Gestión de proyectos con TIC's: introducción a MsProject con un ejemplo pasó a paso. Ideas propias Editorial S.L. Espa-a; 2005. p. 1-110. 